InOedia $\quad \begin{aligned} & \text { InMedia } \\ & \text { The French Journal of Media Studies }\end{aligned}$

6 | 2017

Fields of Dreams and Messages

\title{
The Color Line: African American Artists and Segregation - Musée du Quai Branly
}

\section{Clémentine Tholas-Disset}

\section{(2) OpenEdition \\ 1 Journals}

\section{Electronic version}

URL: http://journals.openedition.org/inmedia/875

DOI: $10.4000 /$ inmedia. 875

ISSN: 2259-4728

\section{Publisher}

Center for Research on the English-Speaking World (CREW)

\section{Electronic reference}

Clémentine Tholas-Disset, « The Color Line: African American Artists and Segregation - Musée du Quai Branly », InMedia [Online], 6 | 2017, Online since 18 December 2017, connection on 23 September 2020. URL : http://journals.openedition.org/inmedia/875 ; DOI : https://doi.org/10.4000/inmedia.875

This text was automatically generated on 23 September 2020

(C) InMedia 


\title{
The Color Line: African American Artists and Segregation - Musée du Quai Branly
}

\author{
Clémentine Tholas-Disset
}

\section{AUTHOR'S NOTE}

Musée du Quai Branly-Jacques Chirac, 37 quai Branly, 75007 Paris.

October 4, 2016 - January 15, 2017

Further information

1 When I was a student in the Latin Quarter, I often walked by the commemorative plaque in honor of African-American writer, Richard Wright, located Rue Monsieur Le Prince. Thanks to Wright and his works, I came across the experience of Black American artists in Paris after World War One, which they commonly described as a liberation and a rebirth compared to the sufferings of being second rank citizens in their mother country. Unfortunately, the French general public hardly recollects the presence of Negro musicians, writers or painters in France except for the song by Josephine Baker, J'ai deux amours performed at Le Casino de Paris in 1930 and 1931. For a long while, only a happy-few scholars and connoisseurs were acquainted with their cultural production. As if the African American community, who said they felt more accepted and empowered in our Gallic nation, had remained almost as invisible in France as they were in America.

2 In 2016, one hundred and twenty years after the Supreme Court ruling Plessy V. Ferguson establishing segregation in the United States, France is finally properly reminded of the existence of the black artists it took under its wing in the 1920s and of their creative heirs thanks to the exhibition "The Color Line: African American Artists and Segregation" curated by philosopher Daniel Soutif. Contrasting with the worn-out vision of segregation through the prism of the Civil Rights movement in the 1950s and 
1960s, the exhibition takes the visitors on a journey mainly through the 1910s to the 1940s (some earlier and more recent works are also presented), to illustrate not so much the last moments of the struggle for equality but the birth and rise of an African American cultural awareness. The pieces collected for the exhibition stand as an artistic challenge to the representations of non-white people elaborated by white people, in order to overthrow traditional patterns of social and cultural submission and domination in the United States.

3 As French museumgoers stroll around a white circumvoluted maze, they are not introduced solely to the distress of segregation in the United States but to the lavishness and boldness of creations born out of racial oppression. The abundance of art works is spectacular and compensates for the inaccuracies in the chronological choices and the absence of some important references such as the official beginning of segregation in 1896, the doctrine "separate but equal" or the beginning of desegregation in schools in 1954. As a result, the exhibition should be envisioned as an extensive overview of African American artistry and sensitivity rather than a historical approach to systematized segregation. It is a graphic experience through "the souls of black folk" to quote W.E.B. Dubois' famous phrasing. The exhibition discloses black activism through visual arts, which started after African Americans were faced with the limits of the Reconstruction Amendments which in theory granted them with US citizenship (1868) and the right to vote (1870).

"The Color Line" unveils what could be called pictorial resistance through a large variety of formats such as paintings, drawings, engravings, book and magazine covers, book illustrations, photographs, advertisements, short documentaries and motion pictures. It redirects the attention of the French public away from the creative forms usually associated with Africans Americans, in particular jazz music. The most striking example may be the decision to screen, in the second room of the exhibition, the tworeeler ${ }^{1}$ A Natural Born Gambler (1916) starring musical hall artist Bert Williams who became the first black motion picture performer. In 2014, the MoMA (Museum of Modern Art, NY) had presented some Biograph reels dating from 1913 showing Williams and other black actors without blackface make-up and paved the way for reconsidering black agency in early twentieth century popular culture. The event at Le Musée du Quai Branly offers a similar (re)discovery of African Americans artists and intellectuals, particularly from the Harlem Renaissance movement - but not only that there are also audiovisual archives illustrating the way black Americans fostered their own representation and voice by mingling European and African heritages.

The French visitor can discover works that are probably unknown to him/her and yet considered classics in the United States, like the paintings and illustrations of Aaron Douglass (Aspects of Negro Life, 1934) or Jacob Lawrence's Migration Series-here presented through a video animation explaining the series and the historical aspects of the Great Migration to the North. Contemporary artists are also showcased in the exhibition, like Mickalene Thomas reinterpreting Courbet's L'Origine du Monde (Origin of the Universe, 2012) or Whitefield Lovell who praises the participation of black soldiers in World War One with the installation Autour du Monde (2008) combining wooden planks, charcoal drawings and globes. Daniel Soutif wishes to give access to the major landmarks in the evolution of the Black American community during the twentieth century and to discuss various themes such as violence and death, being a soldier, gender roles, urban life, iconic leaders, discrimination etc. The recognition of the works of female artists 
like Elizabeth Catlett, Lois Malou Jones or Faith Ringgold is also decisive because recent retrospectives devoted to African American artists gave preference to male painters: Aaron Douglass (Spencer Museum of Art \& Smithsonian American Art Museum, 2007-2008), Jacob Lawrence (MoMA, 2015), Archibald Motley (Whitney Museum of American Art, 2015) and Kerry James Marshall (Museum of Contemporary Art Chicago, 2016). Interestingly, these female artists seemed to offer a forthright vision of violence and racial issues (Mob Victim, 1944; The Flag is Bleeding, 1967) while their male counterparts often directed their work towards the celebration of black people.

The attempt to present in such an exhaustive manner the works of African American artists raises a major problem of accessibility to genuine material. Indeed, too many pieces are not authentic material but reproductions on posters or stickers of documents from the Library of Congress. For example, it is disappointing not to have access to more film excerpts, especially from race films which are only illustrated thanks to posters unable to render the stakes of these all-black film productions. The screening of The Migration Series is an attempt to make up for the regrettable absence of the paintings but it is still a pity the French could not really discover this monument of African American culture from the Philips Collection. Furthermore, some books are introduced but their contents are often not accessible (very few are digitalized), offering only very limited information for the visitor. It may encourage the museumgoer to continue the journey beyond the walls of the museum and explore further these references on one's own but it would have been interesting to enhance more clearly some key passages from African American political and literary production. Moreover, the accumulative effect can also put the visitor at a loss because from time to time he/she doesn't know exactly where to go and what to look at or what the exact use of some items is. Indeed, I wondered why some album jackets by Michael Jackson were displayed in the final rooms. If the gradual whitening of the singer was visible, these pieces did not participate accurately in the debate on self-definition and self-representation offered by the exhibition.

What makes "The Color Line" quite distinctive is the way it exemplifies the cross-media productions of some artists and the sense of a global project to give African Americans a new voice of their own. For instance, Aaron Douglass created large historical paintings but also made illustrations for the covers, book covers and the poems of other Harlem Renaissance spokespeople like Alan Leroy Locke, James Weldon Johnson, Claude McKay or Langston Hughes, or for the newspapers The Crisis or Opportunity: Journal of Negro Life. Jacob Lawrence also worked on different formats and more commercial materials, like posters for the 1972 Olympic Games in Munich or the cover of Time magazine showcasing Reverend Jesse Jackson in 1970. These examples prove the versatility of black American artists and their interest in reconciling high and low culture to tell the story of their community through different mediums. We understand that pictorial creation partook in an all-encompassing experience to convey the vibrancy of African-Americanness and challenge ongoing racial discrimination. The most recent art pieces keep raising the issue of the color line even today as a new form of civil rights activism appeared in the US with the movement Black Lives Matter. The election of Donald Trump as the new president of the United States thanks to the support of a dominantly white electorate continues this debate of the place of nonwhites in American society. 
In conclusion, we should keep in mind that the Paris exhibition takes a political stance by showing how African American culture has gradually become mainstream and how it should be regarded as a vital force in the United States. The origin of the various pieces caught my attention because a large proportion of the art works presented in Paris came from the private collection of Walter O. Evans in Savannah. The individual initiative of Dr. Evans, a surgeon, started in the 1970s enabled the preservation of African American art at a time when neither American people nor American museums were attentive to such productions. Dr. Evans' collection gathers paintings, sculptures, cartoons, rare books and manuscripts. He pioneered exhibitions devoted to black artists and intellectual life and truly helped to secure the African American legacy when there was a cultural void detrimental to the black culture in the United States. In recent years, Evans donated part of his collection to museums in order to transfer his mission of conservation to official institutions and make African American art a national concern. The French exhibition provides the next step as it raises international concern regarding the role of the black community in American culture at large, giving similar historical visibility to minorities as the National Museum of African American History \& Culture which opened in Washington D.C. in September 2016. The Paris exhibition may definitely have been inspired by the NMAAHC and puts forth an aesthetic claim, complementing the Smithsonian's interest for material culture, in order to reassess the contributions of African Americans to American society.

\section{ENDNOTES}

1. A short film from the silent era.

\section{AUTHOR \\ CLÉMENTINE THOLAS-DISSET}

Clémentine Tholas-Disset is associate professor of American Studies at Paris 3- Sorbonne Nouvelle University 